\title{
Hydropower Development and Involuntary Displacement: Toward a Global Solution
}

\author{
Ali VanCleef \\ Indiana University Maurer School of Law, mvanclee@indiana.edu
}

Follow this and additional works at: https://www.repository.law.indiana.edu/ijgls

Part of the Comparative and Foreign Law Commons, Energy Policy Commons, International Humanitarian Law Commons, and the Transnational Law Commons

\section{Recommended Citation}

VanCleef, Ali (2016) "Hydropower Development and Involuntary Displacement: Toward a Global Solution," Indiana Journal of Global Legal Studies: Vol. 23 : Iss. 1 , Article 15.

Available at: https://www.repository.law.indiana.edu/ijgls/vol23/iss1/15

This Note is brought to you for free and open access by the Law School Journals at Digital Repository @ Maurer Law. It has been accepted for inclusion in Indiana Journal of Global Legal Studies by an authorized editor of Digital Repository @ Maurer Law. For more information, please contact rvaughan@indiana.edu.

\section{$\Psi$}

JEROME HALL LAW LIBRARY

INDIANA UNIVERSITY

Maurer School of Law
Blooming ton 


\title{
Hydropower Development and Involuntary Displacement: Toward a Global Solution
}

\author{
ALI VANCLEEF*
}

\begin{abstract}
This Note addresses the effects of hydropower development projects on displaced persons globally. This Note recognizes that the increasing global energy demand puts great strain on nations to provide their people with electricity, but it also suggests that sustainable energy development projects can be carried out in a way that is fair to the indigenous populations surrounding hydropower dams. The current global trend in involuntary displacement involves ignoring certain groups of affected persons while undercompensating directly displaced persons, leading to homelessness, social stigmatization, and extreme poverty for millions of people worldwide. Thus far, there has been no sufficient global solution to this displacement problem, as current solutions do not focus on rehabilitating the communities that lose everything for the construction of these projects. This Note suggests that individual nations must take responsibility for the displacement of indigenous populations in building hydropower development projects for the benefit of the nation, and an international actor, such as the World Bank, must use its resources and discretionary project funding to protect global human rights during the development of hydropower projects.
\end{abstract}

\section{INTRODUCTION}

The world is facing an energy crisis. ${ }^{1}$ This comes as no surprise, as the twentieth century saw the global population grow from 1.6 billion to

* Mary (Ali) VanCleef, Executive Production Editor, Indiana Journal of Global Legal Studies, Volume 23; J.D. 2016 Indiana University Maurer School of Law; B.A. 2013 Indiana University. I would like to thank Professor Jayanth Krishnan for his invaluable guidance throughout the note-writing process. I would also like to thank Vitor Dias for his assistance during the drafting of this Note.

1. See generally David Buchan, The Rough Guide to the Energy CRISIS (2010) (providing information on the energy crisis).

Indiana Journal of Global Legal Studies Vol. 23 \#1 (Winter 2016)

(C) Indiana University Maurer School of Law 
6.1 billion. ${ }^{2}$ In 2004, approximately two billion people did not have electricity in their homes, ${ }^{3}$ and this problem is likely to worsen as the population continues to grow. ${ }^{4}$ To solve the looming energy crisis yet remain sensitive to growing environmental concerns; international leaders look to renewable sources of energy as potential solutions to this problem. ${ }^{5}$ These seemingly innocuous solutions to global energy problems, however, come with their own shortcomings.

Setting aside the environmental problems that come with renewable energy, or, more specifically, hydropower dams, these dams displace millions of persons from indigenous populations surrounding hydropower facilities, and vulnerable populations face what are arguably the most severe consequences of dam construction projects. ${ }^{6}$ While such problems seem to be domestic concerns, these large development projects force indigenous populations out of their native territories into new areas, potentially across national borders, making this a transnational issue. Transnational agencies such as the World Bank have been successful in identifying and assessing the displacement problems that result from such projects from a global perspective; ${ }^{7}$ however, they have not been successful in offering global solutions to the hardships faced by vulnerable populations. Although it is possible to find relevant literature from international agencies discussing these human rights violations, there is a research gap regarding what these agencies can offer to the affected populations at the grassroots level. In sum, there are too few studies calling attention to what can be done globally to ensure fair treatment of the populations most affected by hydropower development projects. This Note, therefore,

2. The ENd OF WORLD POPUlation GROWTH IN THE 21ST CENTURY: NeW Challenges For Human Capital Formation \& Sustainable Development 1 (Wolfgang Lutz, Warren C. Sanderson \& Sergei Scherbov eds., 2013).

3. Sophie Namy, Addressing the Social Impacts of Large Hydropower Dams, 7 J. INT'L POL'Y SOLUTIONS 11, 11 (2007).

4. Energy problems are worsening globally. To read more about energy problems in South Africa, Egypt, or India, see the following sources: Energy in South Africa: Fear of the Dark, THE ECONOMIST (Nov. 30, 2013), http://www.economist.com/news/middle-eastand-africa/21590907-firms-are-asked-use-less-electricity-even-though-economy-weak-fear; David D. Kirkpatrick \& Stanley Reed, Looming Energy Crisis Again Confronts Egypt's Leaders, N.Y. TIMES (May 1, 2014), http://www.nytimes.com/2014/05/02/world/middleeast/ looming-energy-crisis-again-confronts-egypts-leaders.html; Aditya Phatak, India Turns to Nuclear as Energy Crisis Deepens, PHYS.ORg (Sept. 28, 2014), http://phys.org/news/201409-india-nuclear-energy-crisis-deepens.html.

5. See generally BUCHAN, supra note 1 (illustrating the need for renewable energy sources as solutions to environmental concerns).

6. Namy, supra note 3, at 12 .

7. See generally World Bank Group [WBG], Involuntary Resettlement, OD 4.30 (June $1,1990)$. 
is an attempt to fill this gap and offer background for further research on global policymaking, dam construction projects and their social effects, and the hardships of indigenous populations resulting from global development projects.

This Note addresses problems of displacement caused by global hydropower development and proposes a new solution that incorporates national and international accountability and provides more protection of the human rights of displaced persons. Part I examines the current trend of involuntary displacement for hydropower development projects, with specific examples from three countries, to depict how nations vary in displacement practices but are nonetheless all unfair to indigenous populations, leading to global human rights violations. Part II sets out the current practices of involuntary displacement in hydropower development projects and addresses their vulnerabilities. In Part III, I propose a global solution to this involuntary displacement problem, involving both national and transnational actors. Nations should, by law, protect their populations from government takings and provide them with opportunities for effective participation and adequate reimbursement. When national laws are not sufficient to protect involuntarily displaced persons, I apply World Bank policies, as the World Bank's objective of alleviating global poverty and its policies on involuntary displacement align with accepted takings procedures and the protection of basic human rights.

I take three countries as specific examples for an in-depth look at the effects of hydropower development projects within those nations. The Belo Monte Hydro-Electric Power Station in Brazil is the world's third largest development project ${ }^{8}$ and is likely to displace 20,000 to 40,000 people during its construction. ${ }^{9}$ China's Three Gorges Dam has displaced over 1.2 million people and is the world's largest hydropower development project. ${ }^{10}$ Finally, India's displacement practices are discussed throughout, where over 16.4 million people have been displaced due to hydropower development projects. ${ }^{11}$ I choose these three countries because they are important international actors that have explicit provisions within their constitutions providing certain

8. Tiffany Hagler-Geard, Brazil's Belo Monte Dam to Displace Thousands in Amazon, ABC NEWS (June 18, 2012), http://abcnews.go.com/blogs/headlines/2012/06/brazils-belomonte-dam-to-displace-thousands-in-amazon/.

9. See id; Brazil's Belo Monte Dam: Sacrificing the Amazon and its Peoples for Dirty Energy, AMAZON WATCH (last visited Nov. 28, 2015), http://amazonwatch.org/work/belomonte-dam [hereinafter Sacrificing].

10. See Three Gorges Dam, INTERNATIONAL RIVERS, http://www.internationalrivers.org/ campaigns/three-gorges-dam (last visited Jan. 8, 2015) [hereinafter Three Gorges].

11. See Singh Negi \& Sujata Ganguly, Development Projects vs. InTernally Displaced Populations IN INDIA: A LITERATURE BASEd APPRAISAL 6 (2011). 
rights to displaced populations. Although they each include these provisions within their constitutions, not one of these countries follows its own requirements during the construction of hydropower development projects.

The World Bank, as opposed to other transnational institutions, should be the global actor to provide a solution to this problem because it has various transnational resources and a great amount of experience due to its funding of hundreds of development projects over several decades.

\section{The Problem: CURRENT INVOLUnTARy DisplaCEMENT PRACTICES FAIL TO ADEQUATELY COMPENSATE AFFECTED POPULATIONS}

Since the boom in hydropower dam construction beginning in the 1940 s, international leaders have approved about 40,000 large-scale hydropower projects, ${ }^{12}$ and since 1900 , nations have invested over two trillion dollars in the construction of large hydropower projects. ${ }^{13}$ Many benefits are associated with the production of hydropower, as these facilities provide over 80 percent of the renewable energy consumed worldwide while all other sources of renewable energy combined contribute 20 percent. ${ }^{14}$ Today, over 45,000 hydropower dams are used worldwide, and these dams provide about one-fifth of the global energy supply. ${ }^{15}$

Because nations see hydropower dams as sustainable sources of renewable energy, leaders continue to construct new facilities despite the life-altering consequences they have for indigenous populations. In the last half-century, millions of people from global indigenous populations in developing countries have lost their homes, communities, and livelihoods and were cleared out of their native lands to make way for large-scale development projects. ${ }^{16}$ The number of displaced persons globally continues to increase, as over 3,700 new hydropower facilities are expected to be built within the next twenty years. ${ }^{17}$ Estimates of the number of persons displaced worldwide range from forty million to

12. See World Commission on Dams [WCD], Dams and Development: A New Framework for Decision-Making 8 (2000).

13. Id. at xxix.

14. Christiane Zarfl, Global Boom in Hydropower Expected This Decade, U. Copenhagen (Oct. 24, 2014), http://news.ku.dk/all_news/2014/10/global-boom-inhydropower-expected-this-decade/.

15. Namy, supra note 3 , at 12 .

16. See World Commission on Dams, supra note 12 , at $\mathrm{xxx}$.

17. See Zarfl, supra note 14. 
eighty million, ${ }^{18}$ with much of the displacement occurring in Asia, Africa, and Latin America. ${ }^{19}$

This displacement problem is twofold. First, indigenous populations living on the dam construction site are pushed out of their homes. These people are defined as displaced persons, or "those who are forced to move out of their habitat, whether it is individually and formally owned, or a traditional, customarily, and collectively owned area." 20 Second, other groups of people are deprived of their livelihoods, as they live downstream and no longer have access to the life-sustaining and income-producing rivers that were dammed by the hydropower facility. ${ }^{21}$ These project-affected persons, or those who "lose all access to most of their land, but [whose] houses may be left untouched," are not forced to leave their homes, but they face losing their livelihoods to dam construction. ${ }^{22}$

Displaced persons can lose virtually everything due to what is called the resettlement effect, or "the loss of physical and non-physical assets, including homes, communities, productive land, income-earning assets and sources, subsistence, resources, cultural sites, social structures, networks and ties, cultural identity and mutual help mechanisms." 23 On the theory of the resettlement effect, a person's loss of a home or individual property accounts for a small portion of what is actually lost when looking at all aspects of a community lost along with the home, such as the community's social, cultural, and religious life. ${ }^{24}$

Even with these harmful effects on indigenous populations, hydropower projects enjoy government approval in most countries, out of the hope that these new technologies will provide a "catalyst for development" in their countries. ${ }^{25}$ These projects are widely supported, as they will provide "real opportunities to improve quality of life and encourage economic development." 26

18. World Commission on Dams, supra note 12, at 104.

19. Id. at 102 .

20. Walter Fernandes, Indis's Forced Displacement Policy and Practice: Is COMPENSATION UP TO ITS FUNCTIONS? 3 (2008).

21. See id; World Commission on Dams, supra note 12, at 103.

22. FERNANDES, supra note 20 , at $3-4$.

23. Theodore E. Downing, Avoiding New Poverty: Mining-Induced Displacement and Resettlement, 58 MINING, MINS., AND SUSTAINABLE DEV. 1, 3 (2002).

24. See id.

25. Arthur Williams \& Stephen Porter, Comparison of Hydropower Options for Developing Countries with Regard to the Environmental, Social and Economic Aspects, PROCEEDINGS OF THE INTERNATIONAL CONFERENCE ON RENEWABLE ENERGY FOR DEVEloping COUNTRIES 2 (2006), available at http://www.udc.edu/docs/cere/Williams_ Porter.pdf.

26. Id. 
According to a study by the World Bank, the majority of people displaced for hydropower projects are from the poorest and most vulnerable sections of society. ${ }^{27}$ One study of over 100 development projects in India found that 1.6 million people were displaced by these projects and nearly half of the displaced persons were from tribal populations. ${ }^{28}$ Because of forced displacement and loss of livelihood, many indigenous persons who were already poor became even poorerthis is referred to as the "new poverty." 29 "New poverty" arises when "the loss for the poor, of even a small bit of a resource, is devastating." 30 Because these populations already have few resources, the loss of one of these resources-in this case, their rivers-can destroy their livelihoods. ${ }^{31}$ Many people face joblessness, as these rivers provide their incomes, and the hydropower facilities that take these rivers away cannot replace all the jobs they destroy. ${ }^{32}$

Minority groups within indigenous populations are even more vulnerable to impoverishment risks from hydropower displacement. ${ }^{33}$ Those who face the most disastrous effects include the elderly and women. ${ }^{34}$ Once a population loses its land, there is less community support for the elderly, putting this population at particular risk. ${ }^{35}$ Additionally, women in indigenous tribal populations who rely on working the farms, growing gardens, and selling produce lose the lands they once worked and are unable to find new land and employment. ${ }^{36}$ Thus, women can no longer contribute to household income or support themselves.

Hydropower development projects lead to eight destructive displacement risks for indigenous populations: landlessness, joblessness, homelessness, marginalization, food insecurity, increased morbidity, lost access to common resources, and community dislodgment. ${ }^{37}$ There is currently no global solution to address these risks to displaced populations.

27. Namy, supra note 3 , at 13 .

28. Downing, supra note 23 , at 11 .

29. Id. at 8 .

30. Id.

31. See id

32. Id. at 10 .

33. See id. at 11.

34. $I d$.

35. See id.

36. See id. at 12.

37. Michael M. Cernea, Impoverishment RISKS, Risk Management, AND RECONSTRUCTION: A MODEL OF POPULATION DisPlacemENT AND RESETTLEMENT 9 (2004) [hereinafter CERNEA, IMPOVERISHMENT RISKS]. 


\section{A. Displacement Problems at the Belo Monte Hydro-Electric Power Station in Brazil}

Several nations across the globe are experiencing tensions between governments and native populations surrounding hydropower dam sites. While some countries are receiving pushback from their people during the planning stages for the facility, others face problems trying to relocate and rehabilitate the people that were pushed out of their homes and lands after construction began.

The Belo Monte Dam in Para, Brazil, is well under way to being a major hydropower facility, as 50 percent of its construction is already complete. ${ }^{38}$ This seventeen billion dollar dam, which gets its power by diverting 80 percent of the Xingu River, a tributary of the Amazon River, ${ }^{39}$ will be called the Belo Monte Hydro-Electric Power Station, and it will have the capability of producing 11,200 megawatts of electricity when functioning at capacity, which may only happen during the Amazon's rainy season that lasts at most four months out of the year. ${ }^{40}$ For the other eight months of the year, the dam will only generate around 4,571 megawatts of energy. ${ }^{41}$

This energy comes at a great cost financially, but it also comes at a great cost to the native populations surrounding the dam. Around 25,000 indigenous people from eighteen tribes and ethnic groups live adjacent to the Xingu River, and about 20,000 will be displaced by the dam's construction. ${ }^{42}$ Many of these people rely on the river for food, and they also use the river to travel to other cities to sell or trade goods.43 Without this river, these communities will lose their livelihoods and become susceptible to various diseases from a lack of flowing freshwater. ${ }^{44}$

The indigenous populations have resisted these developments. Construction of the Belo Monte Dam has been delayed several times due to more than one dozen legal challenges. ${ }^{45}$ One of these challenges, a class action filed by federal prosecutors against the government and

38. Sacrificing, supra note 9 .

39. Belo Monte: Massive Dam Project Strikes at the Heart of the Amazon, INTERNATIONAL RIVERS (May 2012), http://www.internationalrivers.org/files/attachedfiles/Belo_Monte_FactSheet_May2012.pdf [hereinafter Massive Dam Project].

40. Kenneth Rapoza, Was Brazil's Belo Monte Dam A Bad Idea?, ForBes (Mar. 7, 2014, 5:41 PM), http://www.forbes.com/sites/kenrapoza/2014/03/07/was-brazils-belo-monte-dama-bad-idea/.

41. Id.

42. Massive Dam Project, supra note 39.

43. See id.

44. See id.

45. Id. 
Norte Energia, is awaiting trial in the Supreme Court. ${ }^{46}$ Additionally, the Inter-American Commission on Human Rights took precautionary actions against Brazil, as it believes several human rights violations have occurred during the construction of this dam. ${ }^{47}$

According to the Brazilian Constitution, "Hydric resources . . . in Indian land may only be prospected . . . after hearing from the communities involved, and the participation in the results of such mining shall be ensured to them, as set forth by law." 48 While the dam underwent its licensing process, the Brazilian Institute of Environment and Natural Resources (IBAMA) held public hearings to discuss the benefits of the dam and hear the concerns of native populations. ${ }^{49}$ However, hearings for the Belo Monte Dam were generally meant to inform indigenous populations of the government's decision to build the dam in pro forma fulfillment of the constitutional requirement. Critics assert that the hearings were never intended to actually address the concerns of those who would be affected by the dam. ${ }^{50}$

Moreover, Decree 7,342, which establishes the socioeconomic registration proceedings for populations affected by energy projects, requires that an identification tool or database be kept as public record of the population affected by developments of hydroelectric dams. ${ }^{51}$ Norte Energia, the company building the dam, says on its website that it is "in the process of registration of families" that will be displaced by the dam. ${ }^{52}$ However, the database has never been developed.

Much of the land surrounding the Xingu River belongs to communities rather than individuals; the Brazilian Federal Constitution guarantees indigenous populations a communal right to property. ${ }^{53}$ Areas used for "productive activities... indispensable to the

46. See Vinodh Jaichand \& Alexandre Andrade Sampaio, Dam and Be Damned: The Adverse Impacts of Belo Monte on Indigenous Peoples in Brazil, 35 HUM. RTS. Q. 408, 42829 (2013).

47. See id. at 412.

48. ConstituiçĀo FEDERAL [C.F.] [CONSTITUTiON] art. 231 (Braz.).

49. See Public Hearings on Belo Monte Dam - Democracy or Hypocrisy, INTERNATIONAL RIVERS, https://www.internationalrivers.org/blogs/232/public-hearings-on-belo-montedam-democracy-or-hypocrisy (last visited Nov. 11, 2015).

50. See Public Hearings on Belo Monte Dam - Democracy or Hypocrisy, INTERNATIONAL RIVERS, https:/www.internationalrivers.org/blogs/232/public-hearings-on-belo-montedam-democracy-or-hypocrisy (last visited Nov. 11, 2015).

51. LIFE INST., TECHNICAL DOCUMENTS VOL. II: ENERGY AND BIODIVERSITY: ANALYSIS OF ENVIRONMENTAL LEGAL ASPECTS IN SOUTH AMERICA AND INTERNATIONAL Environmental Treaties Ratified by Brazil 26 (2013) (explaining Decree 7,342).

52. Bianca Jagger, The Belo Monte Dam: An Environmental Crime, InTERNATIONAL RIVERS, http://www.internationalrivers.org/resources/the-belo-monte-dam-an-environmentalcrime-7533 (last visited Nov. 11, 2015).

53. See Jaichand \& Sampaio, supra note 46 , at 426. 
preservation of the environmental resources necessary for their wellbeing" are the property of these communities. ${ }^{54}$ Because these tribes rely on the Xingu River to sustain their livelihoods, this communal property right should be more strongly enforced, and these communities should be adequately repaid and relocated for this loss of property.

\section{B. Displacement Problems at the Three Gorges Dam in China}

China finished construction on its Three Gorges Dam in 2008, and this massive dam is the world's largest hydropower project. ${ }^{55}$ Like Belo Monte, construction of the Three Gorges Dam was controversial, as the facility displaced over 1.2 million people and flooded 1,350 villages. ${ }^{56}$

During the planning stages of the Three Gorges Dam, financiers estimated that the total cost of the dam would be around 200-240 billion yuan, with 100 billion yuan to be used for relocation and resettlement of those displaced. ${ }^{57}$ However, these relocation funds never fully reimbursed affected populations for all of their expenses. ${ }^{58}$ People who were forced to relocate were given lump sums as repayment for their houses, land, and belongings, but the areas where they were forced to relocate were more expensive than their previous homes, forcing them to obtain more money to afford their new homes. ${ }^{59}$ These lumpsum amounts were paid out at a flat rate, with no consideration given to valuations of individual properties. 60 Adding to the problem, minimum basic needs in urban areas where populations were forced to relocate were more expensive than in the rural areas where the people came from, and, as strangers, they also faced higher prices in these urban areas. ${ }^{61}$

Another similarity between the Three Gorges Dam and Belo Monte is the affected populations' lack of access to forums to voice their

54. CONSTITUIÇÃo FEDERAL [C.F.] [Constitution] art. 231 (Braz.).

55. Three Gorges, supra note 10.

56. Id.

57. Sukhan Jackson \& AdRian Sleigh, Resettlement Issues of China's Three GORGES DAM 8 (1.998) (examining the incentives, restraints, and negative externalities of voluntary resettlement).

58. See Jan Trouw, The Three Gorges Dam's Impact on Peasant Livelihood: China's Project on THE YANGTZE RIVER 81 (2007) (investigating the socio-economic consequences for rural people, who were engaged in agricultural activities before resettlement and who were forced to resettle to state-assigned areas which can be rural but also urban).

59. See id.

60. See id. at 31-34.

61. See id. at 100-04. 
opinions about the impending hydropower projects. ${ }^{62}$ Like the populations adjacent to Belo Monte, populations surrounding the Three Gorges Dam had no meaningful opportunity to provide input on the project or discuss their concerns, and they had no say in what they would receive in return for their land and communities that would be taken. ${ }^{63}$

One resettlement project in China, the Shuikou Resettlement Plan of the 1980s and $1990 \mathrm{~s}$, succeeded in resettling and economically rehabilitating displaced persons affected by the Shuikou Dam and Reservoir. ${ }^{64}$ Over 67,000 rural persons and 17,000 urban persons needed to be relocated due to construction of this project. ${ }^{65}$ The United Nations Environment Programme believes this resettlement plan succeeded because it was based on national and provincial regulations combined with relevant World Bank policies on involuntary resettlement.66 In its Operational Directive 4.30, the World Bank's policy on involuntary resettlement states, "[t]he objective of the Bank's resettlement policy is to ensure that the population displaced by a project receives benefits from it." 67 Under this policy, displaced persons are not only reimbursed, but are also entitled to benefits because of the trouble the projects caused them. ${ }^{68}$ The Shuikou Resettlement Plan carried out this policy, and within ten years displaced persons benefitted from improved living standards, including bigger houses and better utilities. ${ }^{69}$ Additionally, the plan created 30,000 jobs, which led to an increase in the income level of displaced persons by 3.8 percent. ${ }^{70}$ Although this project could have served as an example of a widely successful resettlement plan to be followed by the Three Gorges Project, these policies were largely ignored.

62. See id. at 37.

63. See id.

64. See United Nations Environment Programme Dams and Development Project, Compendium on Relevant Practices - 2nd Stage: Revised Final Report: Benefit Sharing Issue, 70-71 (Feb. 10, 2007) [hereinafter Compendium] (discussing decision-making and management of dams and their alternatives and promoting dialogue at the national, regional, and local level and producing non prescriptive practical guidelines).

65. Id. at 73 .

66. See id. at 71.

67. World Bank Group, supra note 7, \3.

68. See id.

69. See Compendium, supra note 64 , at 74 .

70. Id. 


\section{Global Issues: Involuntary Displacement as Transnational Problem}

This problem is not confined within the borders of specific countries. Nations with the highest rates of displacement due to large-scale hydropower projects receive money from global investors to build these dams, ${ }^{71}$ which incentivizes the displacement of their own populations. In fact, in the last decade, global investment in dams was six times what it was in the previous decade. 72 With wealthy investors such as Hydromine in the United States and Sinohydro in China investing hundreds of millions of dollars into hydropower dams in Africa, ${ }^{73}$ and the World Bank funding hundreds of projects worldwide, ${ }^{74}$ this is a global problem with no consistently effective solution.

A global solution is necessary to fix this problem because individual nations are not providing their populations with basic rights during displacement. Since individual nations are not protecting their populations, a transnational protocol must be implemented to protect these vulnerable people. While the importance of state sovereignty cannot be ignored, at times global institutions like the World Bank must step in and set global standards that individual nations must follow. If the World Bank were to step in, it could set minimum standards for how indigenous populations must be treated during displacement, and it could use aid and development packages as incentives for individual nations to comply.

\section{EXTERNALIZING COSTS ONTO INDIGENOUS POPULATIONS: CURRENT COMPENSATION AND PARTICIPATION PRACTICES AND THEIR FAULTS}

Current solutions to global displacement problems have been lackluster and incomplete. Many projects are poorly planned, as project designers and financiers do not take the cost of compensating displaced communities into account during the planning stages for new hydropower developments, and the majority of projects do not use databases to account for and keep track of displaced persons. ${ }^{75}$ Additionally, while indigenous populations have the right to participate in preconstruction hearings for projects and gain access to the proper

71. See Klement Tockner et al., Keynote Address at the 17th Annual River Symposium: Future Boom in Hydropower Dam Construction Will Change the Global Map (Sep. 15-18, 2014).

72. See id.

73. See id.

74. See Namy, supra note 3 , at 11 .

75. See FERNANDES, supra note 20 , at 5 . 
forums to express their preferences for resettlement, ${ }^{76}$ projects rarely provide displaced populations with sufficient access for participation. ${ }^{77}$ Finally, the repayment method used most frequently worldwide is the compensation method, which provides a lump-sum repayment for the market value of property to directly affected persons. ${ }^{78}$ Critics of this scheme note that it does not repay indirectly affected persons who lose their livelihoods to construction of the hydropower facility, nor take social, cultural, or religious values of land into consideration during repayment of directly affected persons. ${ }^{79}$

\section{A. Insufficient Preconstruction Planning and Financing}

Hydropower development groups often fail to consider displacement risks during the planning stages of major hydropower projects, while other development groups draft resettlement plans that do not completely reimburse and rehabilitate displaced persons or those affected by the projects. From 2007 to 2010, the Hydropower Sustainability Assessment Forum, composed of hydropower representatives, government agencies, financiers, and nongovernmental organizations (NGOs), drafted the Hydropower Sustainability Assessment Protocol (HSAP). ${ }^{80}$ This protocol was intended by its drafters to assist hydropower companies in considering the social and environmental performances of their projects by scoring them against similar projects internationally and aimed to help them develop planning tools for future projects. ${ }^{81}$

While it could be an effective protocol for addressing accountability issues, HSAP has problems that must be fixed before it is implemented internationally. First, as pointed out by the International Network on Displacement and Resettlement, the protocol imposes no requirements after the hydropower project has been commissioned. ${ }^{82}$ Because the

76. See U.N. Under-Secretary-General for Humanitarian Affairs and Emergency Relief Coordinator, Guiding Principles on Internal Displacement, art. 7, E/CN.4/1998/53/Add.2 (June 2001) [hereinafter Guiding Principles].

77. See FERNANDES, supra note 20, at 9.

78. Michael M. Cernea, Compensation and Benefit Sharing: Why Resettlement Policies and Practices Must Be Reformed, 1 WATER SCI. \& ENGINEERING 89, 90 (2008) [hereinafter Cernea, Compensation].

79. See id.

80. The Hydropower Sustainability Assessment Protocol, InTERNATIONAL RIVERS, http://www.internationalrivers.org/campaigns/the-hydropower-sustainability-assessmentprotocol (last visited Jan. 9, 2015).

81. Id.

82. INTERNATIONAL NETWORK ON DISPLACEMENT AND RESETTLEMENT, A REVIEW OF The INTERnational HydRoPoWer ASSOCIATION'S DRAFT Protocol FOR ASSESSING THE 
requirements associated with the resettlement plans stop after this point, those implementing the plans can carry them out ineffectively and avoid having to make corrections. ${ }^{83}$ Additionally, in the initial strategic assessment of hydropower projects, HSAP does not require planning groups to consider displacement numbers and costs of rehabilitation. ${ }^{84}$ This consideration should be required at this beginning stage of the protocol, as it would be most beneficial to the planning groups for these costs to be realized up front. ${ }^{85}$

The United Nations (U.N.) put out its Guiding Principles on Internal Displacement as a nonbinding document to assist nations in following the principles of international human rights and humanitarian laws for internally displaced persons. ${ }^{86}$ While this document requires databases to be kept for conflict-generated displaced persons, whom the Office of the United Nations High Commissioner for Refugees (UNHCR) is obligated to protect, ${ }^{87}$ databases are not required for other internally displaced persons, like those displaced by large-scale development projects. ${ }^{88}$ Although these databases are not required, reliable databases are necessary to plan for the resettlement and rehabilitation of displaced persons, as project planners cannot accurately estimate project costs without taking into account the number of persons that will be displaced by the project. ${ }^{89}$ However, even when databases are kept, they may not be effective. ${ }^{90}$ For example, the information in databases in many situations is incomplete and inconsistent, as it comes from diverse sources. ${ }^{91}$ Additionally, after the information is gathered, it is generally not widely accessible to the public, ${ }^{92}$ so those who are affected have no way of knowing if they are in the database.

When data and information are gathered on internally displaced persons, often only people who are directly affected are included in the

Sustainability of Hydropower Dam Projects 2-3 (December 11, 2009) [hereinafter INDR].

83. See id. at 3 .

84. See id.

85. Id.

86. See Guiding Principles, supra note 76.

87. About Us, UNHCR, http://www.unhcr.org/pages/49c3646c2.html (last visited Jan. 4, 2016).

88. UNHCR POPULATION STATISTICS, http://popstats.unhcr.org/\#_ga=1.202480791. 769809356.1419648194 (last visited Jan. 9, 2015).

89. See FERNANDES, supra note 20 , at 5.

90. Norwegian Refugee Council, internally Displaced People: A Global SURVEY 15-16 (2nd ed. 2002).

91. See id. at 15.

92. See id. 
database to be reimbursed.93 Project-affected persons, as discussed above, might not be included, and if they are included, they will never be reimbursed for their losses. ${ }^{94}$ For example, a project leader at a dam in Chile decided to reimburse only those people whose homes would end up underwater from the flooding of the dam; those who were affected in any other way received no compensation. ${ }^{95}$ Additionally, tribes that hold property collectively sometimes are not recognized as property owners because they do not have individual title to the land, so the lands they have lived on for generations are taken without any payment. ${ }^{96}$ For example, property laws in India only recognize individually titled land ownership, and all other lands not formally titled by an individual are state properties. ${ }^{97}$

\section{B. Lack of Preconstruction Participation of Indigenous Populations}

According to the United Nation's Guiding Principles on Internal Displacement, nations must provide complete information to those who will be displaced, including compensation and relocation information. 98 Additionally, " $[\mathrm{t}]$ he free and informed consent of those to be displaced shall be sought." ${ }^{99}$ Like U.N. policies, World Bank Operational Directive 4.30 states, "Community participation in planning and implementing resettlement should be encouraged." 100 This directive recognizes that displaced persons may be more accepting of resettlement plans if they relocate as a community rather than as separate individuals or groups, and preferences such as these can be ascertained from open discussion with soon-to-be displaced persons. ${ }^{101}$ To encourage cooperation, planners and displaced persons should be informed about the other party's intentions and preferences to select a plan that is acceptable to both parties or to consider reasonable alternatives. ${ }^{102}$ Under the United Nations' and World Bank's regimes, indigenous populations displaced by large-scale hydropower projects should be given the right to voice their concerns and be heard before plans are implemented and lands are taken. As noted above, however, opportunities for the participation of indigenous populations are rare and usually insincere.

\footnotetext{
93. See Downing, supra note 23, at 18.

94. See id.

95. Id.

96. See FERNANDES, supra note 20 , at 4.

97. $I d$.

98. See Guiding Principles, supra note 76 at princ. 7(3)(b).

99. Id. at princ. 7(3)(c).

100. World Bank Group, supra note 7, ๆ 3(c).

101. See id. ๆ 7.

102. See id. ๆ 8.
} 
India's National Policy on Resettlement and Rehabilitation was finalized in 2003. This policy does not require the participation of displaced persons or project-affected persons in development projects. ${ }^{103}$ The Resettlement and Rehabilitation Policy was finalized despite evidence showing that failure to involve affected communities in largescale development projects leads to insufficient rehabilitation for displaced populations and poorly planned projects that acquire more land than necessary. ${ }^{104}$

Similar to policies in India, Brazil's laws and policies on displaced persons also fail to incorporate the opinions of displaced populations and illustrate the negative effects of this lack of participation. As discussed above, Article 231, Paragraph 3 of the Brazilian Constitution requires hearings to address the concerns of affected communities in large-scale development projects. ${ }^{105}$ Builders of the Belo Monte Dam and other project planners, however, have not satisfied this requirement by consulting affected populations, and prosecutors have filed several lawsuits to prevent licensing of these projects as a result. 106 The International Labor Organization requires party states, which include Brazil, to get the free, informed participation of indigenous populations before these people are forced to resettle. ${ }^{107}$ However, as discussed above, meetings with affected communities were held before constructing Belo Monte to inform populations what would happen during construction and not to consider or mitigate the harm actually caused by the project. ${ }^{108}$

\section{Flaws of the Compensation Model and the Necessity of Resettlement and Rehabilitation}

The World Bank recognizes in Operational Directive (OD) 4.30 that "[i]nvoluntary resettlement may cause severe long-term hardship, impoverishment, and environmental damage unless appropriate measures are carefully planned and carried out." 109 Recognizing the

\footnotetext{
103. See FERNANDES, supra note 20 , at 9 .

104. See id. at 10.

105. CONSTITUIÇÃo FEDERAL [C.F.] [CONSTITUTION] art. 231 (Braz.).

106. Brazil Threatens to Withhold License for Belo Monte Dam over Mitigation Worries, THE GUARDIAN, http://www.theguardian.com/world/2015/sep/23/brazil-belo-monte-damoperating-licence-withheld (last visited Nov. 11, 2015).

107. Convention No. 169, International Labour Organization (Sept. 5, 1991), http://www.ilo.org/indigenous/Conventions/no169/lang--en/index.htm.

108. See Public Hearings on Belo Monte Dam - Democracy or Hypocrisy, InTERnationaL RIVERS, https://www.internationalrivers.org/blogs/232/public-hearings-on-belo-montedam-democracy-or-hypocrisy (last visited Nov. 11, 2015).

109. World Bank Group, supra note 7, ๆ 2.
} 
negative effects of large-scale development projects on native populations, the World Bank says its purpose with this directive is to ensure that displaced communities receive benefits from these projects. ${ }^{110}$ The OD suggests that involuntary resettlement be avoided or minimized, and it also indicates that resettlement plans should be developed.111 Such plans should require community participation, that affected populations receive social and economic integration after resettlement, and that they receive sufficient land compensation and all other necessary forms of compensation. ${ }^{112}$

The OD also provides that valuation for the property of displaced persons should be based on replacement cost and not just maiket value.113 While the World Bank intended for native populations to receive more than market value for land and wanted projects to reimburse displaced populations for social, cultural, and psychological losses, market value compensation is the only repayment in most countries. ${ }^{114}$ Involuntary resettlements are often underfunded, and affected populations are undercompensated, 115 leading to the decapitalization and impoverishment of displaced persons. ${ }^{116}$

Resettlement is defined as physical relocation, while rehabilitation is defined as the long-term rebuilding of people's livelihoods and assets, reformation of social and cultural links, and psychological acceptance of their situations. ${ }^{117}$ Compensation, which is sometimes used synonymously with resettlement, is the goal of many large-scale operations, but this goal does not focus on rehabilitation or sustainable development. ${ }^{118}$ Many projects are underfinanced, and losses to native populations are underestimated; thus, costs are externalized onto the displaced communities. ${ }^{119}$

Because costs are externalized onto native populations, displaced communities do not receive certain entitlements. ${ }^{120}$ These entitlements include rights to compensation, income restoration, transfer assistance,

110. See id. ๆ 3.

111. See id. If 3(a)-(b).

112. See id. I 3(a)-(e).

113. See id. If 3(b).

114. See Cernea, Compensation, supra note 78, at 90-91.

115. See id. at 91 .

116. See id. at 92 .

117. See FERNANDES, supra note 20, at 4.

118. See Downing, supra note 23, at 3 .

119. See Michael M. Cernea, Research Professor of Anthropology and Int'l Affairs, George Washington Univ., Keynote Address at the United Nations Symposium on Hydropower and Sustainable Development: Social Impacts and Social Risks in Hydropower Programs: Preemptive Planning and Counter-Risk Measures, 7 (Oct. 27-29, 2004).

120. See Downing, supra note 23 , at 13 . 
income substitution, training, and restoration of social bases. ${ }^{121}$ World Bank displacement policy recognizes this rehabilitation goal: OD 4.30 suggests that projects provide alternative employment opportunities for affected populations and provide training for unskilled workers. ${ }^{122}$

The UNHCR's displacement policy provides that "[a]ll internally displaced persons have the right to an adequate standard of living." 23 Observers note that this policy intends that large-scale development projects fund the rehabilitation or sustainable development of affected communities. ${ }^{124}$ Sustainable development involves relocation and rehabilitation, but it also ensures that affected populations are better off than they were before the project, that they become beneficiaries of the project. ${ }^{125}$

Many nations do not recognize the duties of rehabilitation and sustainable development in their internal displacement policies. For example, India's National Policy on Resettlement and Rehabilitation does not make rehabilitation a right, meaning it is not mandatory. ${ }^{126}$ Additionally, only individual landowners get replacement land for areas taken for the project, so tribal communities' rights to replacement lands are not recognized. ${ }^{127}$ This is in conflict with Article 21 of the Indian Constitution, which states that those who pay the price of a project through displacement should have a better standard of living after the project than before it, and that displaced persons deserve "life with dignity." ${ }^{28}$ Compensation for land taken by large-scale developments in India is based on the market value of the land, not its replacement value, ${ }^{129}$ which would take account of economic, social, and cultural values. ${ }^{130}$ In fact, loss of the land itself is only 10 to 20 percent of the impoverishment risk to displaced persons. ${ }^{131}$ As mentioned by tribal leaders displaced by Belo Monte in Brazil, their people have lived on these lands for generations, their "blood is inside the land," so it is more than just an economic asset to them. ${ }^{132}$

Recognizing nonmonetary value in assets is difficult and can lead to inconsistencies. While taking away generational lands leads to lifestyle

121. See id.

122. See World Bank Group, supra note 7, ๆ 18.

123. Guiding Principles, supra note 76, at princ. 18(1).

124. See FERNANDES, supra note 20 , at 6 .

125. See id. at $22-23$.

126. Id. at 11 .

127. See id.

128. Id. at 12-13.

129. See id.

130. See id. at 15.

131. See Downing, supra note 23 , at 8.

132. Massive Dam Project, supra note 39. 
changes and social or cultural losses, ${ }^{133}$ these losses are hard to quantify. The World Bank recognizes that some losses cannot easily be valued, but its policy states that attempts must be made to give displaced persons access to resources and opportunities equivalent to those that were lost. ${ }^{134}$

\section{A NEW SOLUTION INVOLVING NATIONAL AND INTERNATIONAL ACCOUNTABILITY: A NATION-BY-NATION APPROACH WITH INTERNATIONAL OVERSIGHT}

Current solutions are insufficient to resolve global displacement problems, so a new solution must be implemented to protect and rehabilitate vulnerable indigenous populations near planned hydropower facilities. Current solutions are failing because nations are not sufficiently protecting their own people, so a transnational actor like the World Bank must step in and set the parameters for how nations must treat their citizens to receive hydropower development funding. The true solution to this problem requires individual nations to work with a global actor that will set basic human rights parameters and refuse to grant aid and development packages to noncompliant nations.

National governments should be the first line of defense in protecting the rights of indigenous populations within their borders while a transnational actor such as the World Bank should provide oversight during these projects to further protect these rights. The World Bank is one of the largest sources of funds for these projects ${ }^{135}$ and its policies are compatible with supporting the basic human rights of indigenous populations, so it should be willing to take accountability and pull funding on projects that are not meeting the standards set out in its directives. New repayment standards, which would be in line with World Bank directives, should include rehabilitation, benefit sharing, and social and technical training. ${ }^{136}$ If national laws do not meet the global standards set out in World Bank policies, displaced persons and human rights organizations can file complaints with the World Bank Inspection Panel. ${ }^{137}$ The World Bank is not currently equipped to take on all of this responsibility, ${ }^{138}$ so it must reform its policies to provide

133. See FERNANDES, supra note 20 , at 16 .

134. See World Bank Group, supra note 7, ๆ 18.

135. See Namy, supra note 3, at 11.

136. Cernea, Compensation, supra note 78, at 96.

137. The Inspection Panel, THE WORLD BANK, http://ewebapps.worldbank.org/apps/ip/

Pages/AboutUS.aspx (last visited Jan. 12, 2015) [hereinafter Inspection Panel].

138. See Jonathan A. Fox, The World Bank Inspection Panel: Lessons from the First Five Years, 6 GLOBAL GOVERNANCE 279, 287-88 (2000). 
explicit requirements for discretionary funding and enforce its policies without providing for individual exceptions.

While the World Bank may be criticized as a Western institution and may not be trusted by many marginalized communities globally, it has provided funds for several large hydropower development projects in these countries. For example, in India, the World Bank provided 400 million dollars of funding for the Rampur Hydropower Project; the total cost of the project was 670 million dollars. ${ }^{139}$ Additionally, the World Bank funded 648 million dollars of the 922 million dollars required to build the Vishnugad Pipalkoti Hydro Electric Project. ${ }^{140}$ In Nigeria, the World Bank funded 395 million dollars of the 670 million dollars necessary for the Power Sector Guarantees Project, which increased supply of electricity to Nigerian consumers. ${ }^{141}$ Finally, in Mexico, the World Bank funded the entire cost of the Hydroelectric Development Project, which constructed two hydroelectric power plants and helped fund the relocation of affected populations. ${ }^{142}$

Traditionally, the World Bank has provided the most money for the construction of large dams, but, today, various Chinese financial institutions are the largest financiers. ${ }^{143}$ While Chinese financial institutions are not likely to take up the global cause of protecting displaced populations, the World Bank remains a large financier that can be held responsible for the protection of global human rights. Since the World Bank's goals are to "end extreme poverty within a generation and boost shared prosperity," 144 the World Bank should be required to uphold global human rights standards and should not play favorites in requiring that these standards be met by every individual nation that requests funding.

139. Projects \& Operations: Rampur Hydropower Project, THE WORLD BANK, http://www.worldbank.org/projects/P095114/rampur-hydropower-project?lang=en (last visited July 29,2015 ).

140. Projects \& Operations: Vishnugad Pipalkoti Hydro Electric Project, THE WoRLD BANK, http://www.worldbank.org/projects/P096124/vishnugad-pipalkoti-hydro-electricproject?lang=en (last visited July 29, 2015).

141. Projects \& Operations: Nigeria Power Sector Guarantees Project, THE WORLD BANK, http://www.worldbank,org/projects/P120207/nigeria-power-sector-guaranteesproject?lang=en (last visited July 29, 2015).

142. Project \& Operations: Hydroelectric Development Project, THE WORLD BANK, http://www.worldbank.org/projects/P007609/hydroelectric-development-project?lang=en (last visited July 29,2015 ).

143. See Banks and Dam Builders, INTERNATIONAL RIVERS, http://www.international rivers.org/programs/banks-and-dam-builders (last visited Aug. 5, 2015).

144. About, THE WORLD BANK, http://www.worldbank.org/en/about (last visited July 29 , 2015). 


\section{A. The First Line of Protection: National Governments}

One potentially viable solution to this problem is to compel governments to take accountability for development projects and ensure that planning steps are taken before these projects are approved. According to the United Nation's Guiding Principles on Internal Displacement, "[n]ational authorities have the primary duty and responsibility to provide protection and humanitarian assistance to internally displaced persons within their jurisdiction." ${ }^{145}$ Because governments allow hydropower companies to build these facilities in their countries to meet energy demands, government leaders and officials are best positioned to enforce certain requirements, such as databases and budgets for displaced persons, and should accept responsibility for the displacement and impoverishment that results when these requirements are not met. ${ }^{146}$ If hydropower construction companies are not willing to meet these requirements, other companies can be sought out that are willing to take the necessary steps to protect indigenous populations.

Alternatively, some believe that hydropower construction companies should be responsible for meeting human rights requirements. ${ }^{147}$ Because companies bid on these projects and profit from them, they should accept responsibility for the results. ${ }^{148}$ These companies are likely large, rich corporations, so they may have a greater ability to pay for the harms done to displaced persons. However, I suggest that governments take responsibility, as they allow companies to come in, take lands from indigenous populations, and develop facilities for energy. In the case of the Belo Monte Dam, the Brazilian government, not project builders or financiers, has been putting pressure on IBAMA to approve the project so construction can move forward. ${ }^{149}$ From a practical perspective, governments may also be easier to hold accountable than large corporations. 150

Governments, through their constitutions and other mandates, are required to ensure that their citizens are protected from human rights violations. Many constitutions prohibit takings of land and property without just compensation, and governments must uphold these

145. See Guiding Principles, supra note 76, at princ. 3(1).

146. See Downing, supra note 23 , at 16.

147. See id. at 16-17.

148. See id. (arguing that companies should at least evaluate the risks to the displaced, which are not currently given much attention).

149. Alexei Barrionuevo, Brazil Rejects Panel's Request to Stop Dam, N.Y. TIMES (Apr. 5, 2011), http://www.nytimes.com/2011/04/06/world/americas/06brazil.html?_r=0.

150. See Downing, supra note 23 , at 19. 
requirements. Moreover, governments are most capable of hearing and addressing the concerns of their populations. For example, Article 231, Paragraph 3 of the Brazilian Constitution requires hearings before land takings, so the Brazilian government, as enforcer of its laws, should be responsible for holding hearings for displaced persons. ${ }^{151}$ Hearings should be held before displacement occurs to ascertain the most acceptable way for displaced persons to be rehabilitated.152 These rehabilitation requests can then be added to planning requirements before the government allows the project to move forward. This way, the government can pass this information on to project financiers, who could consider rehabilitation costs during the planning stages of the project. ${ }^{153}$

While governments did not take responsibility for displacement in the past, they may be more willing to take responsibility now, as they are receiving new pressures from humanitarian groups and NGOs. ${ }^{154}$ Human rights organizations are concerned about the welfare of displaced persons, and international development banks, like the World Bank, are beginning to take responsibility for their own actions in funding these projects as they face pressure from developed countries. ${ }^{155}$

If governments do not meet their responsibilities to protect their citizens, funding should be cut by the World Bank, which is one of the largest sources of funding for dam construction globally. ${ }^{156}$ In fact, the World Bank provided around 75 billion dollars for nearly 538 dam projects by the end of $1998 .{ }^{157}$ Because the World Bank funds many of these projects, it can impose its policies on governments, which can then place requirements on project planners and financiers. ${ }^{158}$ The World Bank should be willing to enforce involuntary displacement goals in pursuit of its mission of world poverty reduction. ${ }^{159}$

\section{B. Reforming Repayment Methods}

Current methods of repayment for displaced persons are flawed, as they are underinclusive in determining both who receives payment and how much is owed to them. The majority of policies only recognize

151. CONSTITUIÇ̃̃o FeDERAL [C.F.] [CONSTITUTION] art. 231(3) (Braz.).

152. See World Bank Group, supra note 7, 18.

153. See INDR, supra note 82 , at 2-3, 7-8.

154. See Downing, supra note 23 , at 17-18.

155. See id. at 17.

156. See Namy, supra note 3 , at 11 .

157. Id.

158. See id.

159. Id. at 13. 
directly affected persons as those entitled to receive repayment. ${ }^{160}$ However, anyone who loses the beneficial use of rivers or their lands should be reimbursed, not just those whose lands are flooded entirely. ${ }^{161}$ Project-affected persons are impacted because the structural changes to river patterns adversely affect agriculture and fishing and lead to reduced land values, ${ }^{162}$ so they should be reimbursed along with directly displaced populations. The distinction between directly affected persons and project-affected persons also shows the need for databases, as people do not know if their lands will be taken by the project or if they will only be indirectly affected, and thus they have no way of knowing if they will be reimbursed or not. ${ }^{163}$ As an example, financiers of the Hirakud Dam in India claimed the dam's construction displaced 110,000 people, but, when taking account of anyone adversely affected by the project, it actually displaced 180,000 people. ${ }^{164}$ Additionally, repayment should happen before displacement occurs to ensure that the project has allocated enough funds and everyone will be sufficiently repaid. ${ }^{165}$

The amount of compensation should not be set at market value, as market value does not take account of the social, cultural, or religious value of the land.166 Compensation for land at replacement cost, however, can better take these costs into consideration. ${ }^{167}$ Replacement cost also considers the costs of rebuilding a home or purchasing land in the new living area, as the new locations can be much more expensive than the land that was taken from them. ${ }^{168}$ Repayment must also account for the cost of rebuilding an entirely new life. ${ }^{169}$ Finally, compensation should not be paid in one standard lump-sum payment, as this does not leave room for consideration of the sizes of different families and the amount of space necessary for them to live comfortably, and also does not consider the cost of living in the area where they be resettled. ${ }^{170}$

160. See FERNANDES, supra note 20, at 11.

161. See id. at 3-4.

162. See Namy, supra note 3 , at 12 .

163. See FERNANDES, supra note 20, at 13.

164. See id. at 13-14.

165. See World Bank Group, supra note 7, II 3(b).

166. See FERNANDES, supra note 20 , at 13.

167. See World Bank Group, supra note 7, If 14.

168. See Trouw, supra note 58, at 83 .

169. See generally, Vasudha Dhagamwar, The Land Acquisition Act: High Time for Changes, in REHABILITATION POLICY AND LAW IN INDIA: A RIGHT TO LIVELIHOOD 111 (Walter Fernandes \& Vijay Paranjpye eds.,1997) (discussing the history of the Land Acquisition Act and suggesting changes for the future).

170. See Jim Yardley, Chinese Dam Projects Criticized for Their Human Costs, N.Y. TIMES, Nov. 19, 2007, http://www.nytimes.com/2007/11/19/world/asia/19dam.html? pagewanted=all\&_r=2\&. 
Even though compensation is a legal requirement for takings in many countries' constitutions, it is not in itself capable of restoring the livelihoods of displaced persons and improving their lives for the future. ${ }^{171}$ In 1995, the World Bank found that less than 30 percent of resettlement plans went beyond compensation. ${ }^{172}$ However, displaced persons should enjoy rights to resettlement and rehabilitation. ${ }^{173}$ Resettlement is physically moving a displaced person to a new location and is a one-time event, but rehabilitation spans several years, as things can change and new problems can arise as people are trying to settle into new communities. ${ }^{174}$ Rehabilitation includes creating new jobs, forming new livelihoods, and rebuilding communities and social systems so that displaced persons at minimum return to their preproject statuses. 175

Michael Cernea, an expert in involuntary displacement, ${ }^{176}$ claims that even resettlement and rehabilitation are not enough to repay displaced persons, and that therefore "sustainable development" should be the required standard. ${ }^{177}$ Sustainable development involves resettlement and rehabilitation, but it also includes ensuring that people are better off than they were before the project took their lands. ${ }^{178}$ The sustainability of rehabilitation can be threatened by joblessness, homelessness, marginalization, food insecurity, loss of common lands and resources, increased health risks, and social disarticulation, ${ }^{179}$ so these risks must be considered and plans must be implemented for their amelioration. To make displaced persons better off after the project than they were before the project, there also should be a way for project-affected persons and displaced persons to benefit from the project. ${ }^{180}$

Affected persons can benefit from large-scale development projects by becoming "shareholders" in projects through benefit sharing. Benefit sharing means that displaced persons (now shareholders) share in the project's benefits through equity, benefit-sharing arrangements,

171. See Cernea, Compensation, supra note 78, at 89-91.

172. Downing, supra note 23, at 13.

173. See id.

174. See Fernandes, supra note 20 , at 4-5.

175. See Downing, supra note 23 , at 6 .

176. Michael M. Cernea: Full Biography, BROOKINGS, http://www.brookings.edu/experts/ cerneam?view=bio (last visited Jan. 12, 2015).

177. See Cernea, Compensation, supra note 78, at 93.

178. See Downing, supra note 23 , at 13-14.

179. See id. at 8.

180. See Downing, supra note 23, at 13-14; see also Cernea, Compensation, supra note 81 (discussing fair compensation and restoration for people affected by displacement). 
educational investments, development of microenterprises, or grants. ${ }^{181}$ Experts recognize that the benefits of hydropower projects rarely reach the populations who suffered losses from the project, and these displaced communities deserve to benefit from the projects that have uprooted their lives. ${ }^{182}$ Private sector corporations profit substantially from taking these resource-rich lands and building development projects on them, and a portion of these profits should be returned to the displaced communities. A single compensation payment before displacement does not sufficiently repay displaced communities, but benefit sharing can be much more sufficient to support these displaced populations for the future. ${ }^{183}$ However, displaced populations are generally poor and lack access to bank accounts, so their financial participation in such projects may not work properly in some contexts. If the shareholder method is disfavored, affected persons can also benefit from development projects by receiving the fruits of the project, such as giving displaced and project-affected persons free power from the plant. ${ }^{184}$

Beyond compensation, training and social integration may also be included in the resettlement and rehabilitation scheme. ${ }^{185}$ Since displaced persons are outsiders in their new communities, they face a greater risk of marginalization and social stigmatization. ${ }^{186}$ To combat these risks, social preparation, or the prior informed consultation of displaced populations, can build displaced persons' capacities to deal with resettlement in new communities. ${ }^{187}$ Once social capital is lost, symbiotic networks of people previously relied on, like voluntary associations and kinship structures, are torn apart.188 When project planners receive the informed consultation of displaced communities, groups can be moved together and social capital can be protected. If these precautions are not taken, the stress of relocation and loss of social networks can lead to adverse health effects and lower quality of life for displaced persons. ${ }^{189}$ The reconstruction of formal and informal social institutions takes time, but eventual social reconstruction is

181. Downing, supra note 23 , at 14 .

182. See Namy, supra note 3 , at 13.

183. See Cernea, Compensation, supra note 78, at 99-100.

184. See FERNANDES, supra note 20, at 19-20.

185. See generally Cernea, Compensation, supra note 81 (discussing fair compensation and restoration for people affected by displacement).

186. See CERNEA, IMPOVERISHMENT RISKS, supra note 37, at 16 .

187. See Downing, supra note 23, at 12 .

188. See CERNEA, IMPOVERISHMENT RISKS, supra note 37 , at 20-21.

189. See Namy, supra note 3 , at 13. 
crucial for the successful rehabilitation of displaced persons, as these communities support each other socially, culturally, and economically. 190

Displaced persons not only need social and psychological preparation for social and cultural losses; they also need training and psychological preparation to regain employment. ${ }^{191}$ When they forcibly move someone from one economic area to a completely different, more modernized area, dam financiers and constructors should be required to finance the training necessary for displaced persons to find new careers there. Displaced persons often need training for new semiskilled jobs, as many were previously tradesmen or lived off the land as farmers and fishermen, and these professions will no longer support them in these new locations. 192 However, these new skills must result in actual employment for training programs to be effective, so training programs should reflect market demands. ${ }^{193}$

\section{Changes in International Laws and Policies}

Because of its policies on global poverty alleviation and its influence through the funding of hundreds of international development projects, the World Bank should be the first transnational organization to enforce the rights of displaced populations and punish violators of human rights. ${ }^{194}$ Several World Bank policies offer solutions to current displacement problems, and these policies can be reinforced to ensure that governments and project planners do not take advantage of indigenous populations. For example, World Bank OD 4.20 concerns indigenous populations, and aims to ensure that development projects focus on the respect and human rights of indigenous peoples ${ }^{195}$ by requiring the participation of indigenous populations in development plans. ${ }^{196}$ Additionally, World Bank OD 4.30 describes involuntary resettlement procedures and requirements borrowers must meet to obtain money for projects involving involuntary displacement. ${ }^{197}$ This directive requires resettlement plans, compensation at replacement cost paid before displacement, improvement over former living standards,

190. See CERNEA, IMPOVERISHMENT RISKS, supra note 37, at 31-32.

191. See FERNANDES, supra note 20 , at 17.

192. See id. at 18-19.

193. CERNEA, IMPOVERISHMENT RISKS, supra note 37 , at 28 .

194. See generally Namy, supra note 3 (discussing the World Bank's role in large dam projects and its influence on imposition of policy alternatives).

195. See id. at 14.

196. Fox, supra note 138 , at 286.

197. See generally World Bank Group, supra note 7 ("describ[ing] Bank policy and procedures on involuntary resettlement, as well as the conditions that borrowers are expected to meet in operations involving involuntary resettlement"). 
and community participation in resettlement plans. ${ }^{198}$ The purpose of OD 4.30 is to "restore or improve income-earning capacity of displaced persons." 199 These World Bank Operational Directives are consistent with the rehabilitation and sustainable development of displaced populations, and they should be required of governments and project planners before project construction begins.

Involuntary displacement laws in every country should mirror World Bank policies, as the World Bank is one of the largest financiers of dam construction worldwide. ${ }^{200}$ However, many countries only have broad guidelines for involuntary displacement in their constitutional and statutory law, and these requirements should be made more explicit through new law. For example, the Brazilian Constitution requires that hearings occur before indigenous lands are taken, but it does not state who should preside over these hearings, who should be involved in the hearings, or what procedures should be followed during the hearings. ${ }^{201}$ In India, the only relevant law on involuntary displacement is the Land Acquisition Act, but this statute is insufficient to protect displaced populations. ${ }^{202}$ For example, the Act mentions compensation but says nothing about rights to resettlement and rehabilitation, ${ }^{203}$ both recommended by World Bank policy. ${ }^{204}$ Many countries have some type of displacement policy, but the policies may be insufficient or weakly enforced by national governments when permitting large-scale development projects. If nations receiving funding for these projects do not follow World Bank policies, the World Bank should pull the funding and prevent the country from applying for any other loans or grants until requirements are met. ${ }^{205}$ While the World Bank does not fund all development projects, it has funded several hundred hydropower projects internationally, ${ }^{206}$ so requiring that nations develop laws protecting displaced populations and enforcing World Bank policies during Bank-funded projects is a good start.

Claims that national laws and policies do not meet World Bank project standards should be brought to the World Bank Inspection Panel. This panel is composed of impartial fact finders independent

198. See id.

199. Fox, supra note 138 , at 286.

200. Namy, supra note 3 , at 11.

201. See ConSTITUIÇÃo FEDERAL [C.F.] [CONSTITUTION] art. 231 (Braz.).

202. See FERNANDES, supra note 20, at 2.

203. See id.

204. See generally World Bank Group, supra note 7 ("describ[ing] Bank policy and procedures on involuntary resettlement").

205. See What We Do, THE WORLD BANK, http://www.worldbank.org/en/about/what-wedo (last visited Jan. 12, 2015).

206. See Namy, supra note 3 , at 11 . 
from World Bank management and staff, 207 and provides a forum for those who have been affected or are likely to be affected by Bank-funded projects to air their concerns. ${ }^{208}$ However, displaced populations must be informed of these grievance procedures, as they are not widely known, and also need help navigating the highly technical filing process. ${ }^{209}$ While the Panel is capable of correcting human rights violations in development projects, nations have powerful methods of blocking these accountability policies, and the World Bank must counter these obstructions to be effective. ${ }^{210}$

Adding to the problem, several Inspection Panel policies are flawed because they create loopholes for countries to avoid liability or are unenforceable against the Bank's Board of Directors. For example, a claim filed with the Inspection Panel must show that the World Bank itself failed to follow its policies-not just that national actors who implement policies failed to do so. ${ }^{211}$ Moreover, the Bank's Board of Directors has ignored Inspection Panel policies in deciding which projects the Bank will finance, and there is no way to enforce Inspection Panel policies against the Board, making these policies dead letter. ${ }^{212}$ These loopholes must be closed and the Board of Directors must be held accountable in upholding these policies for Inspection Panel hearings to be effective.

For the Inspection Panel effectively to address the concerns of displaced populations, several changes are necessary in current World Bank policies. First, these policies need to include specific requirements because current Bank policies are guidelines, which can easily be ignored. ${ }^{213}$ Policies within the World Bank's Operational Directives could be helpful in protecting the rights of indigenous populations and decreasing human rights violations, but they must be developed into mandatory standards rather than suggestions. ${ }^{214}$ Additionally, the World Bank must develop enforcement methods and stop lending to those nations not following its guidelines. In the 1980s, the World Bank used policy-based lending and conditionality to ensure nations were meeting lending requirements, ${ }^{215}$ and this practice should continue to keep nations accountable. If nations do not set policies to protect

207. Inspection Panel, supra note 137.

208. Id.

209. See Fox, supra note 138, at 295.

210. See id. at 280 .

211. See id. at 285.

212. Id. at $288-89$.

213. Id. at 291 .

214. Id. at $286-87$.

215. Ngaire Woods \& Amrita Narlikar, Governance and the Limits of Accountability: The WTO, the IMF, and the World Bank, 53 INT'L SoC. SCI. J. 569, 570 (2001). 
displaced persons, they should not receive funding, and if they draft protective policies, funding can be granted upon the condition that they follow through with these policies. Finally, the World Bank should adhere to its own policies in funding projects and stop allowing nations to break the rules for the benefit of development, as this undermines the Bank's main goal of global poverty alleviation. ${ }^{216}$

\section{CONCLUSION}

While there is a global energy crisis and nations are attempting to create energy in an environmentally sustainable way, the rights of indigenous populations cannot be ignored in involuntary displacement. Large-scale hydropower development projects have caused numerous human rights violations globally, and current solutions to this everincreasing problem are ineffective and underinclusive.

To fix this problem and remedy human rights violations, individual nations must be held accountable and ensure that their citizens are protected from irreversible harms. However, nations have shown that they cannot be trusted to handle this problem entirely on their own, so they should be held accountable by a powerful global organization like the World Bank. With its goal of poverty alleviation and its funding of the majority of development projects internationally, the World Bank can provide the enforcement mechanisms necessary to prevent injustices, as it can pull funding from nations who deny the basic human rights of their citizens. With a few changes to its own policies, such as creating effective enforcement mechanisms and addressing major loopholes in existing policies, the World Bank can reduce global poverty and become an enforcer of human rights during the construction of hydropower development projects.

216. See Namy, supra note 3, at 13. 